\title{
Derivatized Pentadentate Macrocyclic Ligands and Their Transition Metal Complexes
}

\author{
Muhammad S. Khan*, Nawal K. Al-Rasbi ${ }^{*}$, Edwin C. Constable ${ }^{* *}$, Adrian R. Dale** \\ and Jack Lewis ${ }^{* *}$
}

*Department of Chemistry, College of Science, Sultan Qaboos University, P.O.Box 36, Al Khod 123, Muscat, Sultanate of Oman; ${ }^{* *}$ Department of Chemistry, University of Cambridge, Lensfield Rd., Cambridge CB2 1EW, UK, *Email: msk@squ.edu.om.

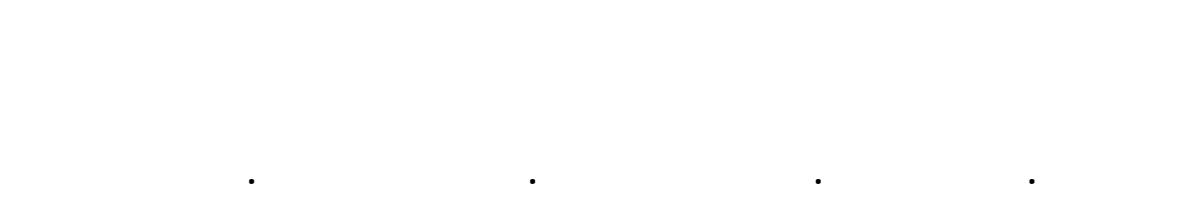

خلاصة: فاعلات مجموعة الهيدروكسي الثل في المركبلت خملسية الحلقة: 1,11 - شنائي (-'2, هيدروكسي الثل)-

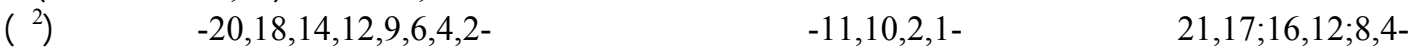

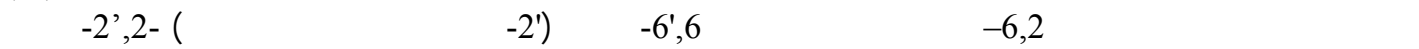

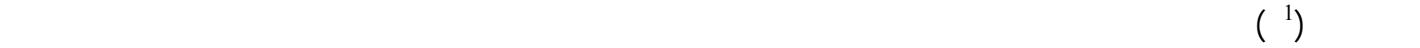

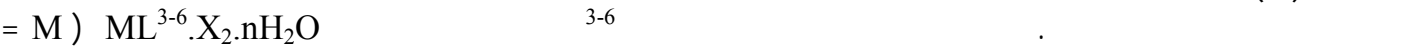

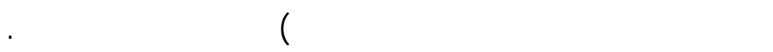

\begin{abstract}
The reaction of the pendant hydroxyethyl group in the planar pentadentate macrocyclic ligand,1,11-bis(2'-hydroxyethyl)-4,8;12,16;17,21-trinitrilo-1,2,10,11-tetraazacyclohenicosa- 2,4,6,9, $12,14,18,20$-octaene $\left(\mathrm{L}^{2}\right)$, derived from the condensation of 2,6-pyridinedialdehyde with 6,6'-bis(2'hydroxyethylhydrazino)-2,2'-bipyridine $\left(\mathrm{L}^{1}\right)$, has been investigated. Esterification reactions are facile, and the reaction of the hydroxyethyl-substituted macrocycle with thionyl chloride yields a chloroethyl derivative. Metal complexes of the new derivatized macrocyclic ligands $\mathrm{L}^{3-6}$ having general formula $\mathrm{ML}^{3-6} \mathrm{X}_{2} \cdot \mathrm{nH}_{2} \mathrm{O}(\mathrm{M}=\mathrm{Mn}, \mathrm{Fe}, \mathrm{Co}, \mathrm{Ni}, \mathrm{Cu}, \mathrm{Zn})$ are readily prepared.
\end{abstract}

KEYWORDS: Macrocyclic Ligands, Coordination Complexes, Transition Metals, Esterification, Functional Group Interconversion.

\section{Introduction}

$\mathbf{M}$ acrocyclic compounds of biological significance, such as the porphyrin, chlorophyll and corrin complexes have been studied for many years (Smith, 1975). More recently, other macrocyclic ligands and their metal complexes have been synthesized (Constable, 1999). The wide range of interest in the synthetic macrocyclic ligand complexes has arisen partly because their similarity to certain biological macrocyclic systems has enabled them to be used as models in the study of these systems. Interest in the synthetic macrocyclic systems also arises due to the unusual properties they may exhibit in their own right. The tendency for a macrocyclic complex to be more stable with respect to ligand dissociation than a comparable open-chain multidentate ligand complex, over and above the chelate affect, is well documented. This phenomenon, termed the 'Macrocyclic Effect' (Cabbinnes and Margerum, 1969) is thought to have both kinetic and thermodynamic origins. Another interesting aspect is the unusual stereochemical arrangement that may be formed on coordination of the macrocyclic ligands to the metal centers. This is particularly true of the pentadentate $\mathrm{N}_{5}$-donor macrocyclic ligands involving $\pi$-electron delocalization around the ring. A rigid stereochemical arrangment is often imposed on the metal that would not occur in 


\section{M.S. KHAN et al.}

the absence of the macrocyclic ligand. The geometry of unsaturated macrocycles is generally planar due to the more favorable overlap of $\pi$-symmetry orbitals. Planar pentadentate $\mathrm{N}_{5}$-donor macrocyclic ligands may form five coordinate planar, six-coordinate pentagonal-based pyramidal and seven-coordinate pentagonal bipyramidal complexes with metal ions (Melson, 1979; Lindoy, 1989). We have been interested in the design, synthesis and coordination chemistry of a series of pentadentate $\mathrm{N}_{5}$-donor macrocycles involving poly-pyridine groups (Figure 1).

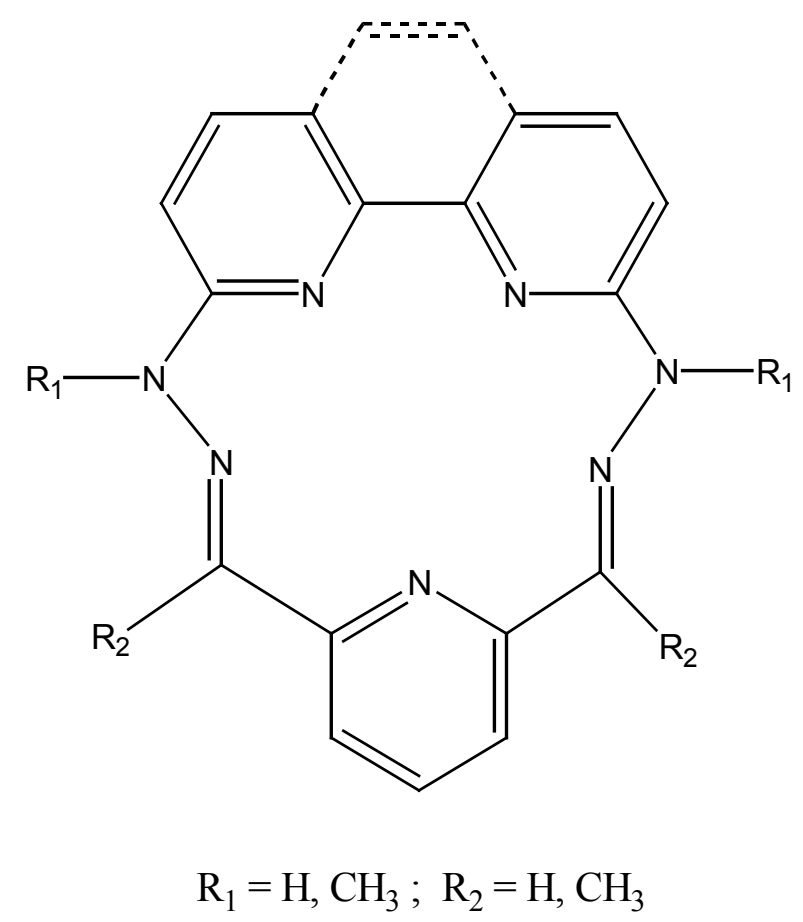

Figure 1. Polypyridyl $\mathrm{N}_{5}$-macrocycles.

The rationale for choosing pyridine derivatives as components within the macrocycle framework is that they readily reduce to radical ions, thereby imparting interesting redox properties to the macrocyclic complexes. The fused rings of 2,2'-bipyridine/1,10-phenanthroline are also expected to impart additional rigidity to the macrcocyle rings. Pentadentate macrocyclic ligands of this type are readily prepared by template or transient template condensations of hydrazinosubstituted 2,2'-bipyridines (Ansell et al 1982a, 1982b, 1983), 1,10-phenanthroline or 2,2':6',2"terpyridines with 2,6-pyridine dicarbonyl (Constable et al, 1985). We have synthesized pentadentate macrocycle $\mathrm{L}^{2}$ with pendant hydroxyethyl group that allows further structural development of the macrocycle by derivatization and the design of biometic systems (Ansell et al, 1983). In this paper we wish to describe the synthesis and coordination chemistry of some such derivatized macrocyclic ligands $\mathrm{L}^{3-6}$ (Figure 2).

\section{Materials and Method}

All reagents were purchased from Sigma Aldrich and used without further purification. Solvents were dried and distilled before use by standard methods. All reactions were performed under $\mathrm{N}_{2}$. Infrared spectra were recorded in compressed $\mathrm{KBr}$ pellet on Perkin Elmer 983 spectrophtometer. ${ }^{1} \mathrm{H}$ NMR spectra were recorded on Bruker WM 250 or AM 400 spectrometers. Fast atom bombardment (FAB) and electron impact (EI) mass spectra were recorded on a Kratos MS 50 mass spectrometer. Microanalysis was performed in the Department of Chemistry, University of Cambridge, U.K. Conductance measurements were made using a Wayne Kerr 


\section{DERIVATIZED PENTADENTATE MACROCYCLIC LIGANDS}

Universal Bridge. The macrocyclic ligand salt $\left[\mathrm{H}_{2} \mathrm{~L}^{2}\right]\left[\mathrm{PF}_{6}\right]_{2}$ was prepared as previously described (Chung et al 1990).

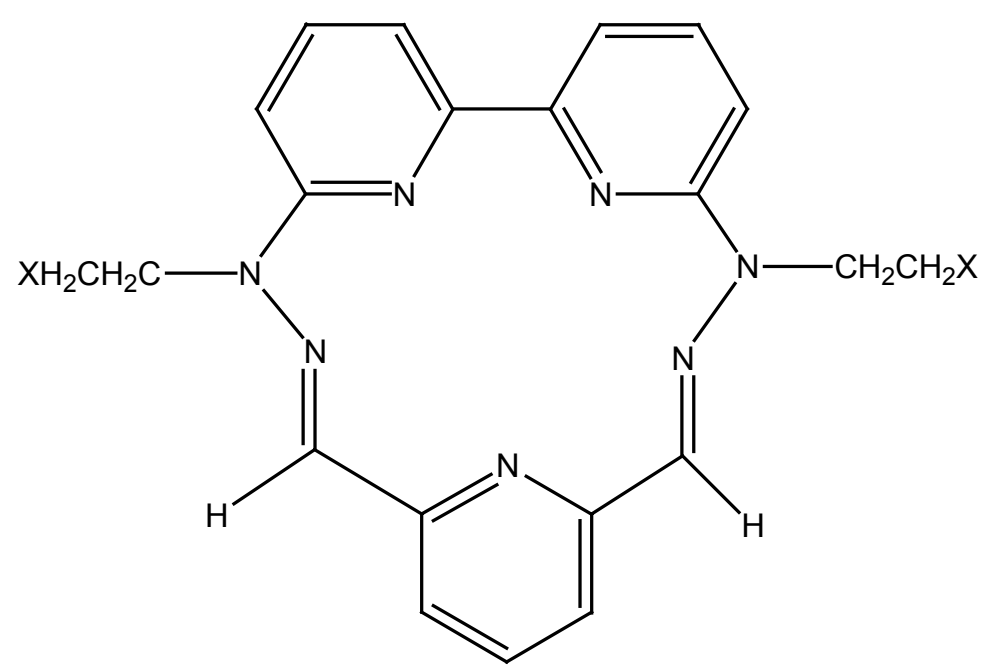

Figure 2. Derivatized $\mathrm{N}_{5}$-macrocylic ligands.

$\mathrm{L}^{2}: \mathrm{X}=\mathrm{OH} ; \mathrm{L}^{3}: \mathrm{X}=\mathrm{O}_{2} \mathrm{CCH}_{3} ; \mathrm{L}^{4}: \mathrm{X}=\mathrm{O}_{2} \mathrm{CCH}_{2} \mathrm{CH}_{3}$;

$\mathrm{L}^{5}: \mathrm{X}=\mathrm{O}_{2} \mathrm{CC}_{6} \mathrm{H}_{5} ; \mathrm{L}_{6}: \mathrm{X}=\mathrm{Cl}$

\section{Synthesis of Derivatized Macrocyclic Ligands $\mathrm{L}^{3-6}$}

\subsection{Synthesis of $\left[\mathrm{H}_{2} \mathrm{~L}^{3}\right]\left[\mathrm{PF}_{6}\right]_{2}$}

A solution of $\left[\mathrm{H}_{2} \mathrm{~L}^{2}\right]\left[\mathrm{PF}_{6}\right]_{2} \cdot \mathrm{H}_{2} \mathrm{O}(0.064 \mathrm{~g}, 0.09 \mathrm{mmol})$ in dry acetonirile $(50 \mathrm{~mL})$ was stirred for 12 hours with acetyl chloride $(5 \mathrm{~mL})$. After twelve hours the orange solution was concentrated in vacuo to $5 \mathrm{~mL}$ volume and treated with water $(50 \mathrm{~mL})$ and sufficient acetonitrile to redissolve the initial precepitate. The solution was then filtered and the filtrate treated with saturated aqueous $\left[\mathrm{NH}_{4}\right]\left[\mathrm{PF}_{6}\right]$ solution $(10 \mathrm{~mL})$. The orange solution was then slowly concentrated in vacuo to yield orange-red crystals of $\left[\mathrm{H}_{2} \mathrm{~L}^{3}\right]\left[\mathrm{PF}_{6}\right]_{2} \cdot \mathrm{H}_{2} \mathrm{O}(0.07 \mathrm{~g}, 96 \%)$. Anal. Found: C, 36.6; H, 3.4; N, 12.4. Calc. for $\mathrm{C}_{25} \mathrm{~F}_{12} \mathrm{H}_{31} \mathrm{~N}_{7} \mathrm{O}_{6} \mathrm{P}_{2}: \mathrm{C}, 36.8 ; \mathrm{H}, 3.6 ; \mathrm{N}, 12.0 \%$. Infrared, $1741 \mathrm{~cm}^{-1}$. EI-MS $(\mathrm{m} / z): 487$.

\subsection{Synthesis of $\left[\mathrm{H}_{2} \mathrm{~L}^{4}\right]\left[\mathrm{PF}_{6}\right]_{2}$}

The procedure was analogous to that described above for $\left[\mathrm{H}_{2} \mathrm{~L}^{3}\right]\left[\mathrm{PF}_{6}\right]_{2}$. Yield: $75 \%$ as orange-red crystals of $\left[\mathrm{H}_{2} \mathrm{~L}^{4}\right]\left[\mathrm{PF}_{6}\right]_{2} \cdot \mathrm{H}_{2} \mathrm{O}$. Anal. Found: 39.5; H, 3.6; N, 11.9. Calc. for $\mathrm{C}_{27} \mathrm{~F}_{12} \mathrm{H}_{33} \mathrm{~N}_{7} \mathrm{O}_{5} \mathrm{P}_{2}: \mathrm{C}, 39.3 ; \mathrm{H}, 3.5 ; \mathrm{N}, 11.9 \%$. Infrared, $1737 \mathrm{~cm}^{-1}$. EI-MS $(\mathrm{m} / z): 515$.

\subsection{Synthesis of $\left[\mathrm{H}_{2} \mathrm{~L}^{5}\right]\left[\mathrm{PF}_{6}\right]_{2}$}

A solution of $\left[\mathrm{H}_{2} \mathrm{~L}^{2}\right]\left[\mathrm{PF}_{6}\right]_{2} \cdot \mathrm{H}_{2} \mathrm{O}(0.10 \mathrm{~g}, 0.14 \mathrm{mmol})$ in dry acetonirile $(50 \mathrm{~mL})$ was heated to reflux for 36 hours with benzoyl chloride $(0.7 \mathrm{~mL})$. The resulting orange solution was concentrated in vacuo to $5 \mathrm{~mL}$ volume when an oil formed. Water $(25 \mathrm{~mL})$ was added and the mixture heated to $90^{\circ} \mathrm{C}$ for 10 minutes to hydrolyse excess benzoyl chloride. The solution was then extracted with diethyl ether $(2 \times 20 \mathrm{~mL})$ and the resulting aqueous suspension treated with sufficient acetonitrile to give a clear solution. This was then filtered and the filtrate treated with saturated aqueous $\left[\mathrm{NH}_{4}\right]\left[\mathrm{PF}_{6}\right]$ solution $(10 \mathrm{~mL})$. The orange solution was then slowly concentrated in vacuo to yield orange-red crystals of $\left[\mathrm{H}_{2} \mathrm{~L}^{5}\right]\left[\mathrm{PF}_{6}\right]_{2} \cdot \mathrm{H}_{2} \mathrm{O}(0.05 \mathrm{~g}, 40 \%)$. Anal. Found: $\mathrm{C}, 68.46 ; \mathrm{H}, 5.18 ; \mathrm{N}, 15.89$. Calc. for $\mathrm{C}_{35} \mathrm{~F}_{12} \mathrm{H}_{31} \mathrm{~N}_{7} \mathrm{O}_{5} \mathrm{P}_{2}$ : C, 68.6; H, 5.1; N, 16.0\%. Infrared, $1720 \mathrm{~cm}^{-1}$. 
Table 1: Analytical data for transition metal complexes of $\mathrm{L}^{3-6}$.

\begin{tabular}{|c|c|c|c|c|c|c|}
\hline \multirow[t]{2}{*}{ Compound } & \multicolumn{3}{|c|}{ Found \% } & \multicolumn{3}{|c|}{ Calc. $\%$} \\
\hline & C & $\mathbf{H}$ & $\mathbf{N}$ & C & $\mathbf{H}$ & $\mathbf{N}$ \\
\hline$\left[\mathrm{MnL}^{3}\left(\mathrm{H}_{2} \mathrm{O}\right)_{2}\right]\left[\mathrm{PF}_{6}\right]_{2} \cdot \mathrm{H}_{2} \mathrm{O}$ & 34.04 & 3.56 & 11.21 & 33.89 & 3.53 & 11.07 \\
\hline$\left[\mathrm{FeL}^{3}\left(\mathrm{H}_{2} \mathrm{O}\right)_{2}\right]\left[\mathrm{PF}_{6}\right]_{2} \cdot \mathrm{H}_{2} \mathrm{O}$ & 34.12 & 3.63 & 10.98 & 33.86 & 3.52 & 11.06 \\
\hline$\left[\mathrm{CoL}^{3}\right]\left[\mathrm{PF}_{6}\right]_{2} \cdot \mathrm{H}_{2} \mathrm{O}$ & 34.99 & 3.64 & 11.39 & 35.16 & 3.66 & 11.48 \\
\hline$\left[\mathrm{NiL}^{3}\left(\mathrm{H}_{2} \mathrm{O}\right)_{2}\right]\left[\mathrm{PF}_{6}\right]_{2} \cdot \mathrm{MeCN}$ & 35.58 & 3.46 & 12.21 & 35.53 & 3.42 & 12.28 \\
\hline$\left[\mathrm{CuL}^{3}\left(\mathrm{H}_{2} \mathrm{O}\right)_{2}\right]\left[\mathrm{PF}_{6}\right]_{2} \cdot \mathrm{H}_{2} \mathrm{O}$ & 33.65 & 3.52 & 11.4 & 33.57 & 3.49 & 10.96 \\
\hline$\left[\mathrm{ZnL}^{3}\left(\mathrm{H}_{2} \mathrm{O}\right)_{2}\right]\left[\mathrm{PF}_{6}\right]_{2} \cdot \mathrm{H}_{2} \mathrm{O}$ & 33.28 & 3.42 & 10.89 & 33.50 & 3.49 & 10.94 \\
\hline$\left[\mathrm{MnL}^{4}\left(\mathrm{H}_{2} \mathrm{O}\right)_{2}\right]\left[\mathrm{PF}_{6}\right]_{2} \cdot \mathrm{H}_{2} \mathrm{O}$ & 35.41 & 3.53 & 10.69 & 35.48 & 3.61 & 10.73 \\
\hline$\left[\mathrm{FeL}^{4}\left(\mathrm{H}_{2} \mathrm{O}\right)_{2}\right]\left[\mathrm{PF}_{6}\right]_{2} \cdot \mathrm{H}_{2} \mathrm{O}$ & 35.38 & 3.68 & 10.63 & 35.45 & 3.61 & 10.72 \\
\hline$\left[\mathrm{CoL}^{4}\right]\left[\mathrm{PF}_{6}\right]_{2} \cdot \mathrm{H}_{2} \mathrm{O}$ & 36.71 & 3.72 & 11.09 & 36.77 & 3.75 & 11.12 \\
\hline$\left[\mathrm{NiL}^{4}\left(\mathrm{H}_{2} \mathrm{O}\right)_{2}\right]\left[\mathrm{PF}_{6}\right]_{2} \cdot \mathrm{MeCN}$ & 36.98 & 3.48 & 11.82 & 37.02 & 3.51 & 11.91 \\
\hline$\left[\mathrm{CuL}^{4}\left(\mathrm{H}_{2} \mathrm{O}\right)_{2}\right]\left[\mathrm{PF}_{6}\right]_{2} \cdot \mathrm{H}_{2} \mathrm{O}$ & 35.28 & 3.47 & 10.72 & 35.15 & 3.58 & 10.63 \\
\hline$\left[\mathrm{ZnL}^{4}\left(\mathrm{H}_{2} \mathrm{O}\right)_{2}\right]\left[\mathrm{PF}_{6}\right]_{2} \cdot \mathrm{H}_{2} \mathrm{O}$ & 36.27 & 3.65 & 10.89 & 36.18 & 3.71 & 10.94 \\
\hline$\left[\mathrm{MnL}^{5}\left(\mathrm{H}_{2} \mathrm{O}\right)_{2}\right]\left[\mathrm{PF}_{6}\right]_{2} \cdot \mathrm{H}_{2} \mathrm{O}$ & 29.97 & 2.57 & 11.67 & 30.10 & 2.53 & 11.70 \\
\hline$\left[\mathrm{FeL}^{5}\left(\mathrm{H}_{2} \mathrm{O}\right)_{2}\right]\left[\mathrm{PF}_{6}\right]_{2} \cdot \mathrm{H}_{2} \mathrm{O}$ & 29.98 & 2.58 & 11.74 & 30.07 & 2.52 & 11.69 \\
\hline$\left[\mathrm{CoL}^{5}\right]\left[\mathrm{PF}_{6}\right]_{2} \cdot \mathrm{H}_{2} \mathrm{O}$ & 31.25 & 2.72 & 12.18 & 31.30 & 2.63 & 12.17 \\
\hline$\left[\mathrm{NiL}^{5}\left(\mathrm{H}_{2} \mathrm{O}\right)_{2}\right]\left[\mathrm{PF}_{6}\right]_{2} \cdot \mathrm{MeCN}$ & 32.07 & 2.47 & 13.01 & 31.94 & 2.45 & 12.96 \\
\hline$\left[\mathrm{CuL}^{5}\left(\mathrm{H}_{2} \mathrm{O}\right)_{2}\right]\left[\mathrm{PF}_{6}\right]_{2} \cdot \mathrm{H}_{2} \mathrm{O}$ & 29.85 & 2.44 & 11.63 & 29.79 & 2.50 & 11.59 \\
\hline$\left[\mathrm{ZnL}^{5}\left(\mathrm{H}_{2} \mathrm{O}\right)_{2}\right]\left[\mathrm{PF}_{6}\right]_{2} \cdot \mathrm{H}_{2} \mathrm{O}$ & 28.09 & 2.28 & 11.01 & 28.14 & 2.36 & 10.94 \\
\hline$\left[\mathrm{MnL}^{6}\left(\mathrm{H}_{2} \mathrm{O}\right)_{2}\right]\left[\mathrm{PF}_{6}\right]_{2} \cdot \mathrm{H}_{2} \mathrm{O}$ & 50.23 & 3.69 & 11.63 & 50.17 & 3.73 & 11.70 \\
\hline$\left[\mathrm{FeL}^{6}\left(\mathrm{H}_{2} \mathrm{O}\right)_{2}\right]\left[\mathrm{PF}_{6}\right]_{2} \cdot \mathrm{H}_{2} \mathrm{O}$ & 50.19 & 3.68 & 11.79 & 50.11 & 3.73 & 11.69 \\
\hline$\left[\mathrm{CoL}^{6}\right]\left[\mathrm{PF}_{6}\right]_{2} \cdot \mathrm{H}_{2} \mathrm{O}$ & 52.23 & 3.94 & 12.24 & 52.16 & 3.88 & 12.17 \\
\hline$\left[\mathrm{NiL}^{6}\left(\mathrm{H}_{2} \mathrm{O}\right)_{2}\right]\left[\mathrm{PF}_{6}\right]_{2} \cdot \mathrm{MeCN}$ & 48.56 & 3.59 & 13.05 & 48.61 & 3.61 & 12.96 \\
\hline$\left[\mathrm{CuL}^{6}\left(\mathrm{H}_{2} \mathrm{O}\right)_{2}\right]\left[\mathrm{PF}_{6}\right]_{2} \cdot \mathrm{H}_{2} \mathrm{O}$ & 49.72 & 3.71 & 11.67 & 49.66 & 3.69 & 11.59 \\
\hline$\left[\mathrm{ZnL}^{6}\left(\mathrm{H}_{2} \mathrm{O}\right)_{2}\right]\left[\mathrm{PF}_{6}\right]_{2} \cdot \mathrm{H}_{2} \mathrm{O}$ & 46.94 & 3.52 & 11.01 & 46.89 & 3.49 & 10.94 \\
\hline
\end{tabular}

\subsection{Synthesis of $\left[\mathrm{H}_{2} \mathrm{~L}^{6}\right]\left[\mathrm{PF}_{6}\right]_{2}$}

A solution of $\left[\mathrm{H}_{2} \mathrm{~L}^{2}\right]\left[\mathrm{PF}_{6}\right]_{2} \cdot \mathrm{H}_{2} \mathrm{O}(0.05 \mathrm{~g}, 0.07 \mathrm{mmol})$ in dry acetonirile $(25 \mathrm{~mL})$ was heated to reflux for 3 hours with thionyl chloride $(1 \mathrm{~mL})$. After this period the orange solution was evaporated to dryness in vacuo and the residue dissolved in acetonitrile $(0.5 \mathrm{~mL})$. Diffusion of diethyl ether vapour into this solution yielded orange-red needles of $\left[\mathrm{H}_{2} \mathrm{~L}^{6}\right]\left[\mathrm{PF}_{6}\right]_{2}(0.03 \mathrm{~g}, 67 \%)$. Anal. Found: 34.34; $\mathrm{H}, 2.97 ; \mathrm{N}, 13.62$. Calc. for $\mathrm{C}_{21} \mathrm{Cl}_{2} \mathrm{~F}_{12} \mathrm{H}_{21} \mathrm{~N}_{7} \mathrm{P}_{2}: \mathrm{C}, 34.42 ; \mathrm{H}, 2.93 ; \mathrm{N}, 13.68 \%$. FAB-MS $(m / z): 439,441,443$. 


\section{DERIVATIZED PENTADENTATE MACROCYCLIC LIGANDS}

\section{Synthesis of Metal Complexes of Derivatized Macrocyclic Ligands}

\subsection{Metal Complexes of $\mathrm{L}^{3}$}

A solution of $\left[\mathrm{H}_{2} \mathrm{~L}^{3}\right]\left[\mathrm{PF}_{6}\right]_{2} \cdot 2 \mathrm{H}_{2} \mathrm{O}$ in $3: 1$ acetonitrile/methanol was treated with a solution of 1 equivalent of an appropriate metal(II) acetate dissolved in the minimum volume of methanol. The mixture was then heated to reflux for 15 minutes, concentrated to $1 / 5^{\text {th }}$ volume in vacuo and treated with saturated $\left[\mathrm{NH}_{4}\right]\left[\mathrm{PF}_{6}\right]$ solution. The products were collected by filtration and dried to yield the desired complexes in a good yield (typically $>75 \%$ ). Analytical data are presented in Table 1 .

\subsection{Metal Complexes of $\mathrm{L}^{4}$}

The procedure was analogous to that used for metal complexes of $\mathrm{L}^{3}$. The desired products were isolated in $>80 \%$ yield. Analytical data are presented in Table 1.

\subsection{Metal Complexes of $\mathrm{L}^{5}$}

The procedure was analogous to that used for metal complexes of $\mathrm{L}^{3}$. The products were isolated in $>80 \%$ yield. Analytical data are presented in Table 1 .

\subsection{Metal complexes of $\mathrm{L}^{6}$}

The procedure was analogous to that used for metal complexes of $\mathrm{L}^{3}$. The products were isolated in respectable yields (typically $>65 \%$ ). Analytical data are presented in Table 1.

\section{Results and Discussion}

Planar pentadentate macrocyclic ligands such as $\mathrm{L}^{2}$ may be prepared by transient template condensations of the appropriate hydrazines $\mathrm{L}^{1}$ with 2,6-pyridinedialdehyde or 2,6 diacetylpyridine. These ligands, which are of particular interest in bearing a functionalized substituent that may be further derivatized to yield encapsulating or capped macrocycles. The open-chain bishydrazines are readily prepared by the reaction of a suitable dihalo compound with $\alpha$-hydroxyethylhydrazine. The free macrocyclic ligand $\mathrm{L}^{2}$ is best prepared as the hydrochloride or other salt by transient template condensations of 6,6'-bis(2'-hydroxyethylhydrazino)-2,2'bipyridine $\left(\mathrm{L}^{1}\right)$ with 2,6 - pyridinedialdehyde in the presence of chromium(III) chloride (Scheme 1).

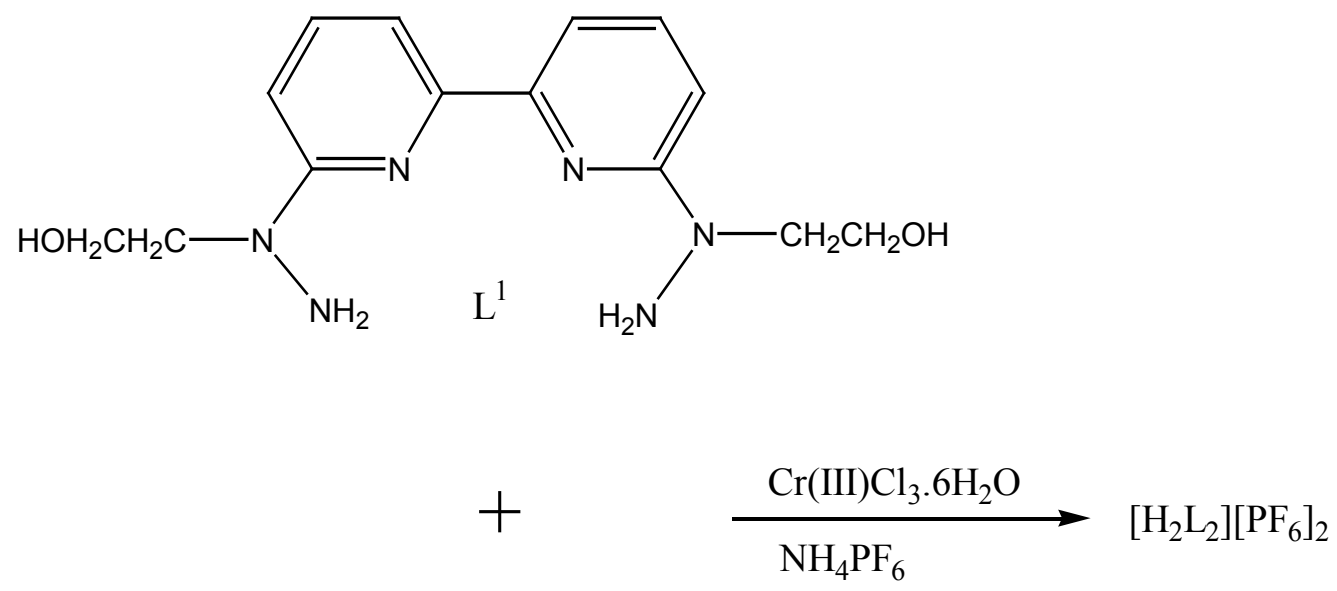<smiles>O=Cc1cccc(C=O)n1</smiles>

Scheme 1. Transient template synthesis of $\mathrm{L}^{2}$. 


\section{M.S. KHAN et al.}

As an initial investigation into the further functionalization of these macrocyclic ligands we studied acylation reactions of $\mathrm{L}^{2}$. Solutions of $\left[\mathrm{H}_{2} \mathrm{~L}^{2}\right]\left[\mathrm{PF}_{6}\right]_{2}$ in acetonitrile changed in color from red to orange upon stirring overnight with excess of acetyl chloride. Treatment of this orange solution with water followed by $\left[\mathrm{NH}_{4}\right]\left[\mathrm{PF}_{6}\right]$ resulted in the formation of an orange crystalline product. In the presence of an excess of acetyl chloride we anticipated the formation of the bisacetylated ligand $\mathrm{L}^{3}$, and microanalysis was in accord with the orange product being formulated $\left[\mathrm{H}_{2} \mathrm{~L}^{3}\right]\left[\mathrm{PF}_{6}\right]_{2} \cdot 2 \mathrm{H}_{2} \mathrm{O}$. The conversion proceeds in a near-quantitative manner, and isolated yields of $96 \%$ of the salt were obtained. The EI mass spectrum of the salt exhibits a parent ion for $\left\{\mathrm{L}^{3}\right\}^{+}$at $m / z$ 487. The infrared spectrum of the compound showed a single strong carbonyl absorption at $1741 \mathrm{~cm}^{-1}$ as expected for the bisacetylated compound. The isolated hexafluorophosphate salt was insufficiently soluble in $\mathrm{D}_{2} \mathrm{O}$ or $\mathrm{CD}_{3} \mathrm{OD}$ to obtain ${ }^{1} \mathrm{H}$ NMR spectra in these solvents, but broadened spectra could be obtained in $\mathrm{CD}_{3} \mathrm{CN}$ or $\mathrm{CD}_{3} \mathrm{COCD}_{3}$. Unfortunately, the resonances assigned to the acetyl groups were obscured in these solvents, and it was necessary to use $\mathrm{CD}_{3} \mathrm{SOCD}_{3}$ solution, and this effect was again observed with $\left[\mathrm{H}_{2} \mathrm{~L}^{3}\right]\left[\mathrm{PF}_{6}\right]_{2}$. The acetyl protons appeared as a singlet $(\delta$ 1.91 ) and integration confirmed that a bisacetylated derivative had been obtained.

A similar smooth reaction occurred when an acetonitrile solution of $\left[\mathrm{H}_{2} \mathrm{~L}^{2}\right]\left[\mathrm{PF}_{6}\right]_{2}$ was stirred with propionyl chloride, and after the usual work up, $\left[\mathrm{H}_{2} \mathrm{~L}^{4}\right]\left[\mathrm{PF}_{6}\right]_{2}$ was obtained as an orange crystalline solid in $75 \%$ yield. Once again, microanalysis was consistent with this formulation, and the EI mass spectrum exhibited a parent ion at $\mathrm{m} / z$ 515. The infrared spectrum showed a singlet strong carbonyl absorption at $1737 \mathrm{~cm}^{-1}$ as expected for the desired bisacylated product. This product is considerably more soluble in $\mathrm{CD}_{3} \mathrm{OD}$ than $\left[\mathrm{H}_{2} \mathrm{~L}^{4}\right]\left[\mathrm{PF}_{6}\right]_{2}$, and sharp well-resolved ${ }^{1} \mathrm{H}$ NMR spectra could be obtained in this solvent. The most evident feature of the spectrum are the triplet $(\delta 1.01,6 \mathrm{H}, \mathrm{J} 7.5 \mathrm{~Hz})$ and quartet $(\delta 2.26,4 \mathrm{H}, \mathrm{J} 7.5 \mathrm{~Hz})$ assigned to the propionyl group. Similar acylations have been demonstrated for other alkanecarboxylic acids, and the reaction appeared to be general.

We also considered the formation of esters with arenecarboxylic acids, and investigated the reaction of $\left[\mathrm{H}_{2} \mathrm{~L}^{2}\right]\left[\mathrm{PF}_{6}\right]_{2}$ with benzoyl chloride under a variety of experimental conditions. The macrocycle was recovered unchanged after stirring a solution of $\left[\mathrm{H}_{2} \mathrm{~L}^{2}\right]\left[\mathrm{PF}_{6}\right]_{2}$ in acetonitrile with benzoyl chloride overnight. We could not obtain benzoylated products from attempted acylation under Schotten-Baumann conditions. Eventually, the desired bisbenzoylated compound was obtained after heating an acetonitrile solution of $\left[\mathrm{H}_{2} \mathrm{~L}^{2}\right]\left[\mathrm{PF}_{6}\right]_{2}$ with an excess of benzoyl chloride to reflux for 36 hours. The product of this reaction tended to be oily, but eventually orange-red crystals of $\left[\mathrm{H}_{2} \mathrm{~L}^{5}\right]\left[\mathrm{PF}_{6}\right]_{2}$ were obtained by repeated crystallization from aqueous acetonitrile. The mass spectrum did not exhibit a molecular ion, but merely showed a fragmentation peak assigned to $\left\{\mathrm{L}^{2}\right\}^{+}$. The infrared spectrum provides firm evidence for the formation of the desired derivatized macrocyclic product and shows strong carbonyl stretching absorption at $1720 \mathrm{~cm}^{-1}$, typical of benzoate esters. The ${ }^{1} \mathrm{H}$ NMR spectrum of the compound in $\mathrm{CD}_{3} \mathrm{SOCD}_{3}$ solution is of interest in showing both broadened and sharp resonances in the aromatic region, Figure 3a. Integration of spectra obtained using very long relaxation delays between pulses indicated that the ratio of the sharp peaks to the broadened peaks was 10:11; this is in accord with the resonances assigned to protons in the macrocyclic ring being broadened as previously noted, but those of the phenyl groups being sharp. The ${ }^{1} \mathrm{H}$ NMR spectrum of the solution of $\left[\mathrm{H}_{2} \mathrm{~L}^{5}\right]\left[\mathrm{PF}_{6}\right]_{2}$ shows temperature dependent behaviour, and upon heating to $370 \mathrm{~K}$ is significantly sharpened, Figure $3 \mathrm{~b}$.

In addition to esterification, we have also investigated other reactions of pendant hydroxyethyl substituent in $\mathrm{L}^{2}$. Numerous attempts to prepare the tosylates by reaction with 4-toluenesulphonyl chloride in a wide range of experimental conditions were unsuccessful. Generally, the products were intractable tars. We have had rather more success in the reaction with thionyl chloride to yield $\mathrm{L}^{6}$. Upon heating acetonirile solutions of $\left[\mathrm{H}_{2} \mathrm{~L}^{2}\right]\left[\mathrm{PF}_{6}\right]_{2}$ with thionyl chloride, orange solutions were obtained, from which the salt $\left[\mathrm{H}_{2} \mathrm{~L}^{6}\right]\left[\mathrm{PF}_{6}\right]_{2}$ could be isolated as orange needles. The microanalysis is in accord with this formulation, and the FAB mass spectrum exhibited a parent ion at $\mathrm{m} / \mathrm{z} 439$, 441,443 showing the expected isotopomeric distribution for a compound containing two chlorine atoms. No absorptoions due to hydroxy groups are observed in the infrared spectrum of the 


\section{DERIVATIZED PENTADENTATE MACROCYCLIC LIGANDS}

compound. Once again, the complex exhibits a broadened ${ }^{1} \mathrm{H}$ NMR spectra in $\mathrm{CD}_{3} \mathrm{SOCD}_{3}$ solution.

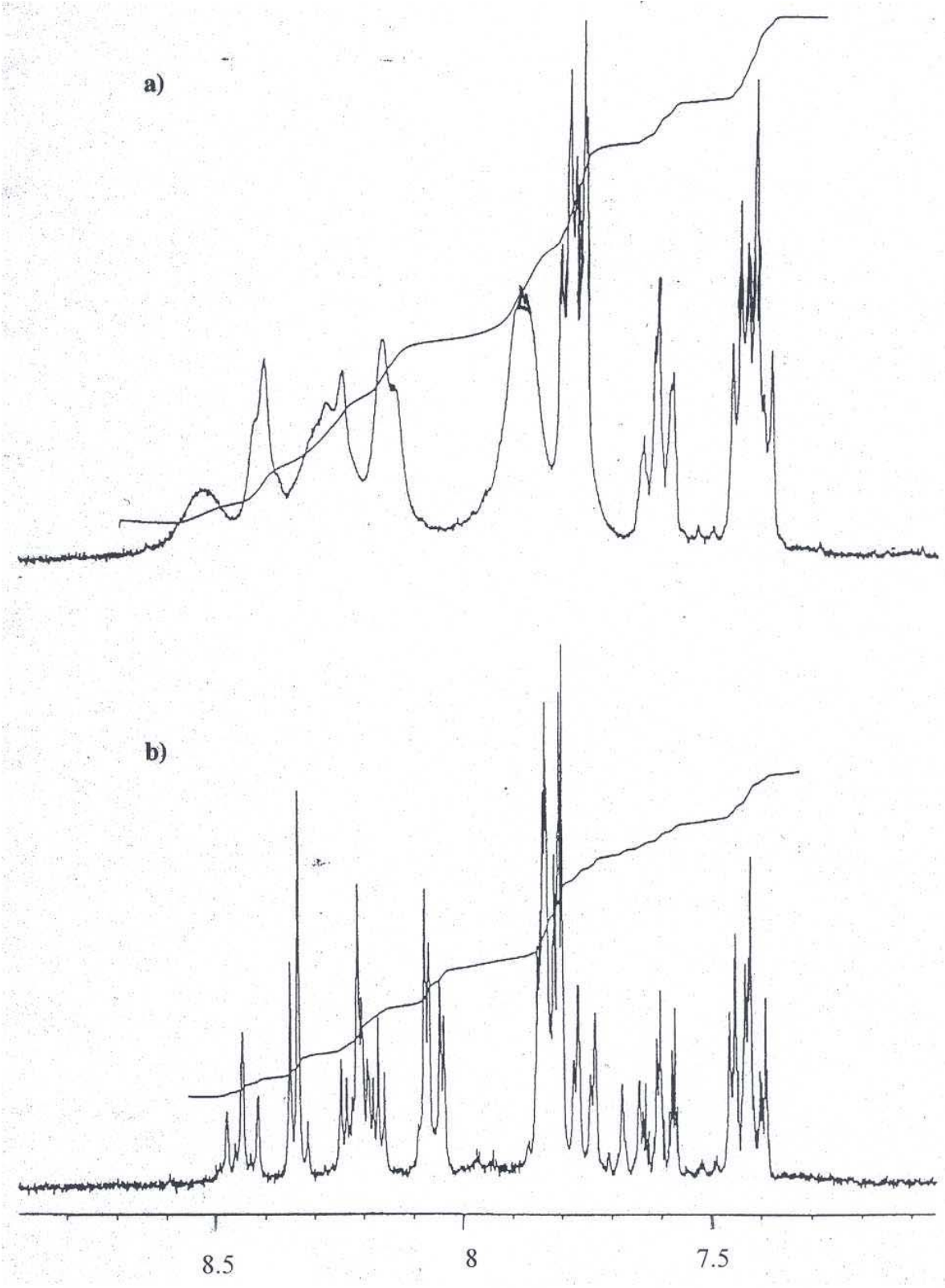

Figure 3. ${ }^{1} \mathrm{H}$ NMR spectrum of a $\mathrm{CD}_{3} \mathrm{SOCD}_{3}$ solution of $\left[\mathrm{H}_{2} \mathrm{~L}^{5}\right]\left[\mathrm{PF}_{6}\right]_{2}$ at: a) $298 \mathrm{~K}$ and b) $370 \mathrm{~K}$.

We have made preliminary studies of the coordination behaviour of the derivatized ligands. The salts $\left[\mathrm{H}_{2} \mathrm{~L}^{3-6}\right]\left[\mathrm{PF}_{6}\right]_{2}$ react smoothly with metal acetates in boiling methanolic solution to yield metal complexes, which may be recrystallized from aqueous acetonitrile to yield the crystalline complexes $\left[\mathrm{ML}^{3-6}\right]\left[\mathrm{PF}_{6}\right]_{2} \cdot \mathrm{nH}_{2} \mathrm{O}(\mathrm{M}=\mathrm{Mn}, \mathrm{Fe}, \mathrm{Co}, \mathrm{Ni}, \mathrm{Cu}, \mathrm{Zn})$. In the absence of any structural data we propose that these complexes possess pentagonal bipyramidal geometries, in which the two axial sites are occupied by coordinated water. The infrared spectra exhibited sharp absorptions at $3604 \mathrm{~cm}^{-1}$ due to the coordinated water molecules. In the solid state, considerable shifts of the carbonyl stretching frequency occurred upon coordination of $\mathrm{L}^{3-5}$, Table 2 . This suggests that there is significant hydrogen-bonding interaction between the coordinated water and the carbonyl groups. Conducivity in nitromethane (see Table 2) indicates that all the complexes are 2:1 electrolytes (Geary, 1971) corresponding to the presence of two counter ions per macrocyclic complex. Taken in conjunction with the analytical data and infrared spectra, conductivity measurements provide very strong evidence for pentagonal bipyramidal coordination geometry for transition metal complexes of the derivatized macrocyclic ligands. 
Table 2: Carbonyl stretching frequency and conductivity of the complexes.

\begin{tabular}{|c|c|c|}
\hline & $v_{\mathrm{CO}}\left(\mathrm{cm}^{-1}\right)$ & $\Lambda\left(\mathrm{Ohm}^{-1} \mathrm{~cm}^{2} \mathrm{~mole}^{-1}\right)$ \\
\hline$\left[\mathrm{MnL}^{3}\left(\mathrm{H}_{2} \mathrm{O}\right)_{2}\right]\left[\mathrm{PF}_{6}\right]_{2} \cdot \mathrm{H}_{2} \mathrm{O}$ & 1716 & 165 \\
\hline$\left[\mathrm{FeL}^{3}\left(\mathrm{H}_{2} \mathrm{O}\right)_{2}\right]\left[\mathrm{PF}_{6}\right]_{2} \cdot \mathrm{H}_{2} \mathrm{O}$ & 1714 & 160 \\
\hline$\left[\mathrm{CoL}^{3}\right]\left[\mathrm{PF}_{6}\right]_{2} \cdot \mathrm{H}_{2} \mathrm{O}$ & 1707 & 167 \\
\hline$\left[\mathrm{NiL}^{3}\left(\mathrm{H}_{2} \mathrm{O}\right)_{2}\right]\left[\mathrm{PF}_{6}\right]_{2} \cdot \mathrm{MeCN}$ & 1723 & 162 \\
\hline$\left[\mathrm{CuL}^{3}\left(\mathrm{H}_{2} \mathrm{O}\right)_{2}\right]\left[\mathrm{PF}_{6}\right]_{2} \cdot \mathrm{H}_{2} \mathrm{O}$ & 1739 & 158 \\
\hline$\left[\mathrm{ZnL}^{3}\left(\mathrm{H}_{2} \mathrm{O}\right)_{2}\right]\left[\mathrm{PF}_{6}\right]_{2} \cdot \mathrm{H}_{2} \mathrm{O}$ & 1723 & 164 \\
\hline$\left[\mathrm{MnL}^{4}\left(\mathrm{H}_{2} \mathrm{O}\right)_{2}\right]\left[\mathrm{PF}_{6}\right]_{2} \cdot \mathrm{H}_{2} \mathrm{O}$ & 1715 & 164 \\
\hline$\left[\mathrm{FeL}^{4}\left(\mathrm{H}_{2} \mathrm{O}\right)_{2}\right]\left[\mathrm{PF}_{6}\right]_{2} \cdot \mathrm{H}_{2} \mathrm{O}$ & 1716 & 163 \\
\hline$\left[\mathrm{CoL}^{4}\right]\left[\mathrm{PF}_{6}\right]_{2} \cdot \mathrm{H}_{2} \mathrm{O}$ & 1710 & 166 \\
\hline$\left[\mathrm{NiL}^{4}\left(\mathrm{H}_{2} \mathrm{O}\right)_{2}\right]\left[\mathrm{PF}_{6}\right]_{2} \cdot \mathrm{MeCN}$ & 1721 & 165 \\
\hline$\left[\mathrm{CuL}^{4}\left(\mathrm{H}_{2} \mathrm{O}\right)_{2}\right]\left[\mathrm{PF}_{6}\right]_{2} \cdot \mathrm{H}_{2} \mathrm{O}$ & 1737 & 160 \\
\hline$\left[\mathrm{ZnL}^{4}\left(\mathrm{H}_{2} \mathrm{O}\right)_{2}\right]\left[\mathrm{PF}_{6}\right]_{2} \cdot \mathrm{H}_{2} \mathrm{O}$ & 1724 & 163 \\
\hline$\left[\mathrm{MnL}^{5}\left(\mathrm{H}_{2} \mathrm{O}\right)_{2}\right]\left[\mathrm{PF}_{6}\right]_{2} \cdot \mathrm{H}_{2} \mathrm{O}$ & 1718 & 161 \\
\hline$\left[\mathrm{FeL}^{5}\left(\mathrm{H}_{2} \mathrm{O}\right)_{2}\right]\left[\mathrm{PF}_{6}\right]_{2} \cdot \mathrm{H}_{2} \mathrm{O}$ & 1715 & 163 \\
\hline$\left[\mathrm{CoL}^{5}\right]\left[\mathrm{PF}_{6}\right]_{2} \cdot \mathrm{H}_{2} \mathrm{O}$ & 1710 & 165 \\
\hline$\left[\mathrm{NiL}^{5}\left(\mathrm{H}_{2} \mathrm{O}\right)_{2}\right]\left[\mathrm{PF}_{6}\right]_{2} \cdot \mathrm{MeCN}$ & 1724 & 167 \\
\hline$\left[\mathrm{CuL}^{5}\left(\mathrm{H}_{2} \mathrm{O}\right)_{2}\right]\left[\mathrm{PF}_{6}\right]_{2} \cdot \mathrm{H}_{2} \mathrm{O}$ & 1735 & 162 \\
\hline$\left[\mathrm{ZnL}^{5}\left(\mathrm{H}_{2} \mathrm{O}\right)_{2}\right]\left[\mathrm{PF}_{6}\right]_{2} \cdot \mathrm{H}_{2} \mathrm{O}$ & 1725 & 161 \\
\hline$\left[\mathrm{MnL}^{6}\left(\mathrm{H}_{2} \mathrm{O}\right)_{2}\right]\left[\mathrm{PF}_{6}\right]_{2} \cdot \mathrm{H}_{2} \mathrm{O}$ & - & 160 \\
\hline$\left[\mathrm{FeL}^{6}\left(\mathrm{H}_{2} \mathrm{O}\right)_{2}\right]\left[\mathrm{PF}_{6}\right]_{2} \cdot \mathrm{H}_{2} \mathrm{O}$ & - & 162 \\
\hline$\left[\mathrm{CoL}^{6}\right]\left[\mathrm{PF}_{6}\right]_{2} \cdot \mathrm{H}_{2} \mathrm{O}$ & - & 164 \\
\hline$\left[\mathrm{NiL}^{6}\left(\mathrm{H}_{2} \mathrm{O}\right)_{2}\right]\left[\mathrm{PF}_{6}\right]_{2} \cdot \mathrm{MeCN}$ & - & 165 \\
\hline$\left[\mathrm{CuL}^{6}\left(\mathrm{H}_{2} \mathrm{O}\right)_{2}\right]\left[\mathrm{PF}_{6}\right]_{2} \cdot \mathrm{H}_{2} \mathrm{O}$ & - & 164 \\
\hline$\left[\mathrm{ZnL}^{6}\left(\mathrm{H}_{2} \mathrm{O}\right)_{2}\right]\left[\mathrm{PF}_{6}\right]_{2} \cdot \mathrm{H}_{2} \mathrm{O}$ & - & 160 \\
\hline
\end{tabular}

\section{Conclusion}

We have shown that derivatized planar pentadentate ligands may be prepared by esterification and functional group interconversions of suitable hydroxyethyl substituted macrocyclic ligand. These ligands appear to possess a coordination chemistry which parallels that of related unsubstituted ligand.

\section{Aknowlegments}

We would like to thank the Department of Chemistry, College of Science, Sultan Qaboos University, Oman and the Engineering and Physical Sciences Research Council (EPSRC), U.K. for financial support. 


\section{DERIVATIZED PENTADENTATE MACROCYCLIC LIGANDS}

\section{References}

SMITH, K.M. 1975. Porphyrins and Metalloporphyrins; Elsevier, Amsterdam.

CONSTABLE, E.C. 1999. Coordination Chemistry of Macrocyclic Compounds, Oxford Science Publications.

CABBINNES, D.K. and MARGERUM, D.W. 1969. Macrocyclic effect on the stability of copper (II) tetramine complexes. J. Amer. Chem. Soc. 91: 6540-6541.

LINDOY, L.F. 1989. The Chemistry of Macrocyclic Ligand Complexes, Cambridge University Press, Cambridge.

MELSON, G.A. 1979. Coordination Chemistry of Macrocyclic Compounds, Plenum, New York.

ANSELL, C.W.G., LEWIS, J., LIPTROT, M.C., RAITHBY, P.R. and SCHRODER, M. 1982. The stabilization of low oxidation state transition metal complexes. Preparation and electrochemistry of cobalt(II) unsaturated macrocyclic complexes and the stabilization of a cobalt(II) derivative. Crystal and molecular structure of $\left[\left(\mathrm{Co}(\mathrm{II})(\mathrm{L})\left(\mathrm{CH}_{3} \mathrm{OH}\right)_{2}\right]\left[\mathrm{BF}_{4}\right]_{2}\right.$ and $\left[\mathrm{Co}(\mathrm{I})(\mathrm{L})\left\{\mathrm{P}-\left(\mathrm{OCH}_{3}\right)_{3} \mathrm{Cl}\right\}\left[\mathrm{PF}_{4}\right]\right.$. J. Chem. Soc., Dalton Trans.: 1593-1601.

ANSELL, C.W.G., LEWIS, J., RAITHBY, P.R. and O'DONOGHUE, T.D. 1983. Synthesis of a macrocyclic metal complex incorporating peripheral hydroxyethyl tails: the X-ray structure of $\left[\mathrm{Mn}\left(\mathrm{L}^{1}\right) \mathrm{Cl}\right]\left[\mathrm{PF}_{4}\right]$. J. Chem. Soc., Dalton Trans.: 177-179.

ANSELL, C.W.G., LEWIS, J., RAITHBY, P.R. and RAMSDEN, J.N. 1982. Synthesis and X-ray structure of a macrocyclic Pentagonal Bipyramidal Complex of Cobalt(II). J. Chem. Soc., Dalton Trans.: 2127-2129.

CHUNG, L.Y., CONSTABLE, E.C., DALE, A.R., KHAN, M.S., LIPTROT, M.C., LEWIS, J. and RAITHBY, P.R. 1990. The transient template effect: chromium(III)-directed synthesis of metal-free macrocyclic ligands and crystal structure of 1,11-bis(2'-hydroxyethyl)4,8,12,16,17,21-trinitilo-1,2,10,11-tetra-azacyclohenicosa-2,4,6,9,12,14,18,20-octaene hydrochloride tetrahydrate. J. Chem. Soc., Dalton Trans.: 1397-1404.

CHUNG, L.Y., CONSTABLE, E.C., KHAN, M.S., LEWIS, J., RAITHBY, P.R. and VARGAS, M.D. 1984. Structural characterization of a pentagonal bipyramidal macrocyclic chromium(III) complex, an explanation of a chromium-mediated-template effect. J. Chem. Soc., Chem Commun.: 1425-1426.

CONSTABLE, E.C., KHAN, F.K., LEWIS, J., LIPTROT, M.C. and RAITHBY, P.R. 1985. The preparation and coordination chemistry of 2,2':6',2"-terpyridine macrocycles. Structural characterization of an intermediate in a transient template reaction. J. Chem. Soc., Dalton Trans.: 333-335.

Received 27 June 2001

Accepted 20 November 2002 